\begin{tabular}{|c|c|}
\hline ב & $\begin{array}{c}\text { International Journal of Current Research } \\
\text { and Academic Review }\end{array}$ \\
\hline & 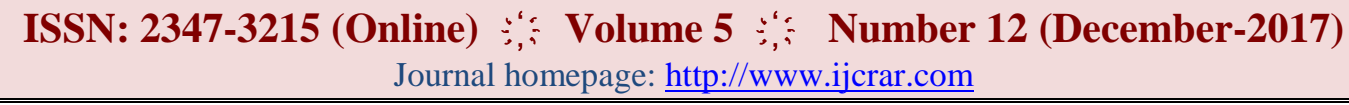 \\
\hline
\end{tabular}

doi: https://doi.org/10.20546/ijcrar.2017.512.006

\title{
Isolation, Cultivation and PCR Conformation of Chicken Anaemia Virus Isolates in Broiler Chicks of Coastal Region of Andhra Pradesh, India
}

\author{
N. Sandhya ${ }^{1}$, K. V. Subramanyam ${ }^{2}$, D. V. R. Sai ${ }^{1}$ and D. V. R. Gopal ${ }^{1 *}$ \\ ${ }^{I}$ Department of Virology, S.V. University, Tirupati, Andhra Pradesh, India \\ ${ }^{2}$ Department of pathology, Veterinary University, Vijayawada, Andhra Pradesh, India \\ *Corresponding author
}

\begin{tabular}{|c|c|}
\hline Abstract & Article Info \\
\hline \multirow{12}{*}{$\begin{array}{l}\text { Chicken Anaemia Virus (CAV) is an emerging disease of poultry especially in young } \\
\text { chickens causing economic losses worldwide. High mortality in CAV infections were } \\
\text { due to immunosuppression associated secondary bacterial and fungal infections. The } \\
\text { disease was characterized by aplastic anaemia, haemorrhages in the muscle, thymus } \\
\text { atrophy and immunosuppression. CAV infection is easily identified based on } \\
\text { symptoms exhibited by diseased flocks. So the diagnosis of chicken anaemia virus is } \\
\text { mainly based on external and clinical symptoms exhibited by infected chickens. } \\
\text { Reduced haematocrit values were clearly observed in infected chicks after two weeks } \\
\text { of post inoculation. Pathognomic signs and lesions exhibited by the affected flock. } \\
\text { Tentatively the diagnosis can usually be made based on flock history, clinical signs, } \\
\text { haematological changes and gross pathological findings in affected birds. PCR } \\
\text { conformation is a specific diagnostic method used for conformation of virus by using } \\
\text { quality primers to detect the CAV. For confirmatory diagnosis isolation and } \\
\text { identification of the CAV is done. Reduced haematocrit (PCV) values are the sensitive } \\
\text { indicator to identify clinically affected birds with CAV following experimental } \\
\text { exposure. Monitoring of CIAV infection by virus isolation, cultivation along with } \\
\text { application of molecular diagnostic tools such as polymerase chain reaction (PCR), etc. } \\
\text { can be used for confirmatory diagnosis of CAV infection. }\end{array}$} & $\begin{array}{l}\text { Accepted: } 28 \text { November } 2017 \\
\text { Available Online:20 December } 2017\end{array}$ \\
\hline & Keywords \\
\hline & \\
\hline & \\
\hline & $\begin{array}{l}\text { Virus, } \\
\text { Haematocrit value, }\end{array}$ \\
\hline & Immunosuppression. \\
\hline & \\
\hline & \\
\hline & \\
\hline & \\
\hline & \\
\hline & \\
\hline
\end{tabular}

\section{Introduction}

The production and consumption of eggs and poultry meat has been increasing worldwide over the last three decades as the consumption of eggs has doubled and that of chicken meat has tripled (Jeurissen et al., 1992). Some viruses that infect poultry industry causing serious economic losses chicken infectious anaemia is one of the emerging viral disease in all developing countries, the diseases still play a predominant role in deciding the economic returns from the poultry industry. According to
Sainsbury (1992), tropical countries have more problems with infectious diseases due to the climatic circumstances. Chicken anaemia virus was distributed worldwide. It was first isolated from Japan in 1970 by Yuasa et.al in commercially produced chickens. Later it was isolated from U.S., U.K., India, and all other developing, poultry meat producing countries.

Chicken Infectious Anaemia disease caused by Chicken Anaemia Virus is an emerging (Kataria et al., 2005; Dhama et al., 2008; Schat, 2009; Oluwayelu, 2010; Bhatt 
et al., 2011; Snoeck et al., 2012; Gowthaman et al., 2013; Nayabian and Mardani, 2013) economically important non-oncogenic immune suppressive viral disease of poultry belongs to family Circoviridae genus Gyro virus (Pringle, 1999). Small non-enveloped virus resistant to thermal inactivation and treatment with lipid solvents and many of the common disinfectants (Von Bulow and Schat, 1997) contains single stranded circular, positive sense DNA having the genome size of 2.3.Kbp. It has different nomenclature as Chicken Anaemia Agent (CAA), Chicken Infectious Anaemia Virus (CIAV), and Blue wing disease (Von Bulow, 1991; Pope, 1991; Toro et al., 2000; Hagood et al., 2000; Schat et al., 2003; Dhama et al., 2008). CAV is an economically important pathogen with a world-wide distribution (Rosenberger and Cloud, 1998; Todd, 2000). Outbreaks of the disease were characterized by severe anaemia, thymus atrophy, bone marrow aplasia and immunosuppression (Van Den Berg, 1996; Adair, 2000; Todd, 2004). Four chicken anaemia virus (CAV) isolates (CAV-A, -B, -E and -P) recovered from different geographical regions of India were characterized, The genome encodes for three viral proteins namely VP1, VP2 and VP3 forms three overlapping open reading frames ORF1, ORF2, ORF3.Vp1 is the major capsid protein encodes $50 \mathrm{KDa}$ protein which is used for diagnostic studies. Chicken anaemia agent is more pathogenic in respect to immunosuppression. The disease is characterised by generalized lymphoid atrophy, increased mortality and severe anaemia. CAV replicates in lymphocytes and causing destruction of thymic lymphocytes, is directly cytotoxic to bone marrow haematopoietic precursor leading to transient anaemia and immunosuppression.

Chicken Anaemia agent (CAA) causes increased mortality in young chickens now it was the major problem that causes economic losses in Andhra Pradesh state of India. The present study was done along coastal belt of Andhra Pradesh India where large no. of poultry forms were established and high mortality rates observed in past four years.

VP1 gene of Chicken Infectious Anaemia Virus was used to develop diagnostics for early detection at field level to reduce economic loses to the poultry industry. Based on some external symptoms the tissue samples were collected from different poultry industries present along the coastal belt of Andhra Pradesh. The samples were clinically confirmed by inoculating the virus in one day old chicks by taking haematocrit values and they were molecularly confirmed by PCR. The polymerase chain reaction (PCR) is a biochemical technology in molecular biology to amplify a single or a few copies of a piece of DNA across several orders of magnitude, generating thousands to millions of copies of a particular DNA sequence For this conformation we used the diagnostic primers which were already reported for VPI gene of CAV. So the PCR was run by specific standardization protocols. The present study is mainly focussing to confirm the incidence of CAV in Andhra Pradesh, India.

\section{Materials and Methods}

\section{Sample collection and Preservation}

Suspected samples were collected from coastal regions of Andhra Pradesh based on specific symptoms exhibited by infected birds. Nearly 160 suspected samples were collected from different areas. Glycerol saline buffer (as transporting media) was used to collect the tissue samples to maintain the virus viability for long time storage. The collected samples were stored at $-20^{\circ} \mathrm{c}$ for further use.

\section{Partial purification of virus}

Partial purification of virus from the tissue samples was done by maceration with sterile motor and pestle by the use of acid washed sand in phosphate buffer saline. All this process carried out in fully sterile conditions at $40 \mathrm{c}$ to maintain the viability of virus. The macerated solution was taken in to sterile eppendorf tubes. The tubes were centrifuged in refrigerated centrifuge at $4^{0} \mathrm{c}$ for 20 minutes at $15000 \mathrm{rpm}$. Then the supernatant was collected. Again the supernatant was centrifuged in refrigerated centrifuge at $1200 \mathrm{rpm}$ for 10 minutes. The supernatant was collected and pellet was discarded. The supernatant contained the partially purified viral DNA. The partially purified virus was added with the antibiotic gentamycin to control the microbial contamination.

\section{Cultivation and Propagation of virus}

This partially purified virus is directly inoculated in to one day old specific pathogen free (SPF) chicks to propagate the virus. (Bisgaard, 1983; Engstrom et al., 1988; Yuasa et al., 1979; Vielitz et al., 1987; Chettle et al., 1989). Nearly 60 one day old specific pathogen free chicks were taken from poultry hatchery nearer to Chittoor district. In that 30 birds were maintained as control. And the remaining 30 birds were inoculated with partially purified chicken anaemia virus by the use of 
insulin syringes. The inoculums size is $5 \mathrm{cc}$ in insulin syringe. This experiment was done in under aseptic controlled conditions. Before the experiment 3 birds were sacrificed for collection of blood to estimate the PCV values.

The haematocrit values were taken from these control samples and values were noted. After one week of inoculation again 3 chicks from control or healthy and 3 chicks from inoculated were sacrificed and blood was collected to vials coated with anticoagulant.

Then these blood samples were used to take haematocrit values and the values were compared with healthy sample values. This experiment was repeated in regular week intervals until the fourth week of inoculation.

\section{Clinical studies}

From the collected blood samples hematocrit values were taken. Blood samples were collected by puncture of wing vein. Samples were used to obtain Packed Cell Volume (PCV), an integral part of complete blood count results along with hemoglobin, total RBC count, total WBC count and platelet count. The PCV was determined by using standard methods.

\section{Isolation of DNA from tissue samples}

DNA was isolated from the collected tissue samples by high salt concentration method illustrated by. (Ausubel et al., 1992)

\section{PCR conformation of Chicken Anemia Virus}

CAV DNA extracted from tissue samples by the method of Todd et al., (26) was amplified with the forward primer 5'-GACCCAC(AT)TGTACGGGGCGAGA-3' and the reverse primer 5'-CCGCTGGTG (AG)T(CT)GCTGC-3' (Crowther et al., 2003): Standard PCR mixtures $(50 \mathrm{ml})$ contained $1 \mu \mathrm{l}$ of $10 \mathrm{mM}$ dNTP, 2 $\mu 1$ of $25 \mathrm{mM} \mathrm{MgCl} 2,0.2 \mathrm{mM}$ forward and reverse primers, $0.5 \quad \mu \mathrm{l}$ TaqDNA polymerase (Thermo Scientifics) and $2 \mu \mathrm{l}$ template DNA. Each reaction was allowed to take place for 30 cycles without initial denaturation step and each consisting of $45 \mathrm{~s}$ at $94^{\circ} \mathrm{c}, 1$ $\min$ at $46^{\circ} \mathrm{c}$ and $1 \mathrm{~min}$ at $72^{\circ} \mathrm{c}$.

A final extension $72^{\circ} \mathrm{c}$ for $30 \mathrm{~min}$ fallowed by holding at $4 \mathrm{c}$. Five $\mu \mathrm{l}$ of amplified product was checked in $1 \%$ agarose gel electrophore3sis with DNA molecular marker.

\section{Results and Discussion}

The inoculated birds were observed regularly for symptom notifications. The following symptoms were observed in regular intervals of time.

Before inoculation six birds were sacrificed and the blood was subjected to count the PCV values. Because the birds were specific pathogen free there is no significant difference between the standard values (27$42 \%$ ) and values which were obtained (Table.1).

The symptoms like decreased feed uptake, the birds become weak and pale were observed after one weak of post inoculation. Blood samples from six infected birds were taken to count PCV values. Drastic change was observed in all samples (Table.2\&3).

Symptoms like paleness of skin, ruffled feathers, severe anemia and subcutaneous hemorrhage was observed after two weeks of inoculation. Again six alternative birds were sacrificed to collect blood and PCV values were noted down. PCV values were decrease when compared to values which were obtained after one week of inoculation. (Table.4\&5)

Secondary bacterial and fungal infections were noticed like bluish green coloration of wings (this disease is also called as blue wing disease), gangrenous dermatitis, and poor growth were the symptoms noticed after third week of inoculation. And the PCV values were drastically decreased (Table.6\&7)

The birds totally stops the feed uptake (Feed off). All inoculated chicks were died because of severe anemia associated with secondary bacterial and fungal infections. Because it is an immunosuppressive of virus the wings become bluish green due to associated secondary fungal infections (bile wing disease). PCV values were decreased (Table 8\&9).

So there was drastic decrease in hematocrit values were observed in regular intervals of time and finally the death of birds occurred after fourth week of inoculation due to the severe anemia and secondary microbial infections. The dead chicks were dissected and the post mortem reports reveals the symptoms like paleness of internal organs including heart, liver, lungs, kidneys, bone marrow, and muscle were observed. In severe cases bone marrow become yellowish fluid. So based on above hematocrit results, symptoms and post mortem reports the CIA virus was clinically confirmed. 
Fig.1 Illustration of the PCR results for CAV from tissue samples collected at 10 to 14 days post infection from inoculated SPF chickens from the in vivo virus isolation assay showing the bands at 464 bp region when compared with $1 \mathrm{~Kb}$ DNA ladder

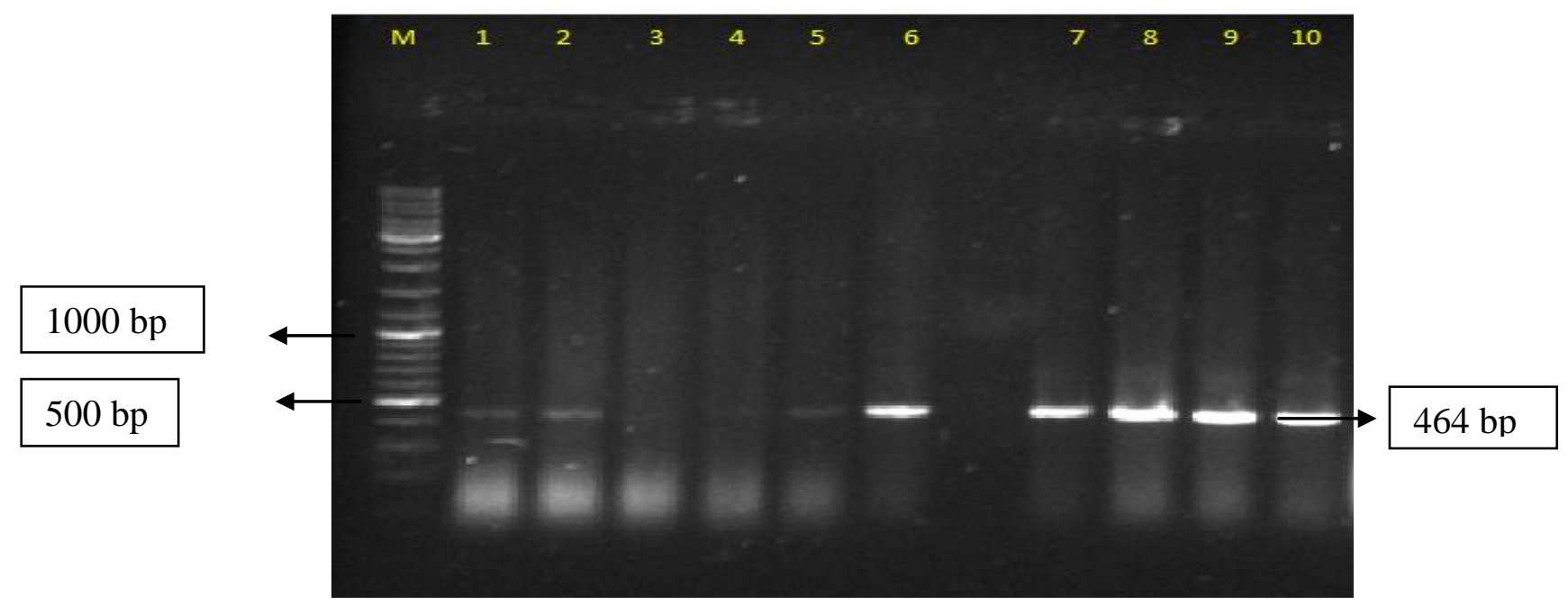

\section{Polymerase Chain Reaction Amplification}

Analysis by agarose gel electrophoresis indicated that a single DNA fragment (464 bps) was produced when DNAs extracted from collected field samples. So the sample contains the VP1 gene of Chicken Infectious Anemia virus. The amplicon size in PCR was 464 bps. Out of 160 samples 121 samples were positive for CAV. chicken anemia virus is molecularly confirmed with in collected field samples from state of Andhra Pradesh.

The poultry and egg industry is India's most valuable agricultural sector. The poultry industry has dramatically increased in size over several decades to supplement needs of increased population. Andhra Pradesh is the leading poultry meat producing state within India and it accounts for one fifth of the poultry meat as well as egg production in the country. About $30 \%$ of its broiler output and $15 \%$ of the egg output are exported to other states in India

Some bacterial, fungal and viral diseases that can affect the poultry forms causes serious economic losses. Chicken Infectious Anemia virus is one of the major economically important emerging poultry viruses that can cause great economic loses to poultry industry by decreasing meat production (Hagood et al., 2000). CAV was an economically significant because of the clinical disease associated with vertical transmission and because of its potential for inducing immune dysfunction alone on in combination with other pathogens. They both are immunosuppressive diseases that are associated with secondary bacterial and fungal diseases McNulty et al., (1988). No vaccine was available for CAV till now. So early detection of virus in field conditions is very much needed to reduce the mortality rates in forms, now the present studies were mainly focusing on development of early diagnostics for CAV. Early detection can reduce the risk of infection and can also reduce the economic losses. Chicken anemia virus (CAV) was the immunosuppressive virus affecting young chickens, characterized by generalized lymphoid atrophy, increased mortality and severe anemia in chickens. CAV replicates in lymphocytes causing destruction to thymic lymphocytes (Jeurissen et al., 1992) and is directly cytotoxic to bone marrow hematopoietic precursors, leading to transient anemia and immunosuppression. However, maternal antibodies prevent the clinical signs of disease but do not prevent infection and transmission of the virus or immunosuppression (Sommer and Cardona, 2003)

In present study some field samples were collected from different areas based on histopathalogical symptoms and they were molecularly confirmed by Polymerase Chain Reaction (PCR).

The propagation of CAV is very difficult when compared to other viruses. Because this virus was only cultivated in MDCC-MSB1 cell lines. The maintenance of this cell lines was very difficult in laboratory. In egg inoculations the virus will give very less titer. So for CAV propagation in one day old chickens was very useful to get better viral proportions. After inoculation 
the chicks were regularly observed for symptoms. Before inoculation and after inoculation the blood samples were collected from the experimental chicks to observe the hematocrit values. The blood samples were collected by sacrificing the chicks into vials coated with an anticoagulant. The hematocrit values containing total RBC count, total WBC count, platelet count, packed cell volume, and hemoglobin percentage. So there was a drastic decrease in hematocrit values were observed in regular week intervals. The inoculated birds were died after the fourth week of inoculation due to severe anemia and secondary microbial infections. The post mortem of the dead chicks shows the symptoms like paleness of internal organs like heart, lungs, kidney, liver and muscle. And the bone marrows become yellowish fluid.

Based on the above observations and results the virus was clinically and molecularly confirmed as CAV, in future which will helpful in development of early diagnostics to reduce the incidence of disease

\section{Acknowledgment}

This study was supported by Department of Science and Technology, Inspire Programme by providing financial support

\section{References}

Adair BM. Immunopathogenesis of chicken anemia virus infection. Dev Comp Immunol 2000; 24, 247-255

Ausubel FM, Brent R, Kingston RE, Moore DD, Seidman JG, SMITH, J.A.; STRUHL, K. Current protocols in molecular biology. New York: Greene Publishing Association; Wiley-Interscience, 1992.

Bello W, Kwa A. "The GATT Agreement on Agriculture and Food Security: The Philippines Case, 1998.

Bhatt P, Shukla SK, Mahendran M, Dhama K, Chawak MM and Kataria JM. Prevalence of chicken infectious anemia virus (CIAV) in commercial poultry flocks of northern India: a serological survey. Transbound Emerg dis, 2011; 58: 458-460

Bisgaard M. An age related and breeder flock associated hemorrhagic disorder in Danish broilers Nord Vet Med. 1983; 35, 397-407.

Chettle NJ, Stuart J, and Wyeth PJ. Outbreak of virulent infectious bursal disease in East Anglia. Vet. Rec. 1989; 125: 271-272

Cloud SS, Rosenberger JK and. Lillehoj HS. Immune dysfunction following infection with chicken anemia agent and infectious bursal disease virus. II. Alterations of in vitro lymphoproliferation and in vivo1192 immune responses. Vet. Immunol. Immunopathol 1992; 34: 353-366

Crowther RA, Berriman WL, Curran GM and Todd D. Comparison of the structures of three circoviruses: Chicken anaemia, porcine circovirus type 2 , and beak and feather disease virus. Journal of virology, 2003; 77: 13036-13041.

Dhama K, Mahendran, M, Somvanshi, R and Chawak, MM Chicken infectious anemia virus: an immunosuppressive pathogen of poultry $-\mathrm{A}$ review. Indian J. Vet. Pathol. 2008; 32: 158-167.

Engstrom BE, Fossum $\mathrm{O} \&$ Luthman M. Blue wing disease of chickens: Experimental infection with a Swedish isolate of chicken anaemia agent and an avian reovirus. Avian Pathol. 1988; 17, 33-50.

Gowthaman V, Singh SD, Dhama K, Barathidasan R, Asok Kumar M, Desingu PA, Mahajan NK, Ramakrishnan MA. Fowl Adeno virus (FAdV) in India: evidence for emerging role as primary respiratory pathogen in chickens. Pakistan Journal of Biological Sciences, 2013.

Hagood LT, Kelly TF, Wright JC and Hoerr FJ. Evaluation of chicken infectious anaemia virus and associated risk factors with disease and production losses in broilers. Avian Dis, 2000; 44: 803-808.

Jeurissen SHM, Wagenaar F, Pol JMA, Van den Eb A J and Note born MHM. Chicken anaemia virus causes apoptosis of thymocytes after in vivo infection and of cell lines after in vitro infection. Journal of Virology, 1992; 66: 7383-7388.

Jordan F. T. W. and Pattison M. 1998. Poultry Disease. 4th Ed., W.B. Saunders company Ltd. pp: 229-232.

Kataria JM, Dhama K, Dash BB, Sylvester SA and Rahul S et al., Emerging viral diseases of poultry in India: Their diagnosis and control. Proceedings of the National Symposium on Emerging and Exotic Diseases of Poultry, March 10-11, 2005, IVRI, UP, India

Nayabian H, and Mardani K. Molecular characterization of chicken anemia virus isolated from broiler farms of west- baijan, Iran. Avian Pathology 2013; 42(2);108-13

Oluwayelu DO. Diagnosis and epidemiology of chicken infectious anemia in Africa. African Journal of Biotechnology. 2010; 9 (14): 2043-2049

Pope C R. Chicken anaemia agent. Vet. Immunol. Immunopathol. 1991; 30: 51-65.

Pringle CR. Virus taxonomy at the XIth International Congress of Virology Sydney Australia. Arch Virol. 1999; 144, 2065-2070

Rosenberger JK. A Laboratory Manual for the Isolation and Identification of Avian 
Sainsbury D. Poultry Health and Management, 3rd, Blackwell Scientific Publications, 1992.

Schat KA, Saif YM, Barnes HJ, Fadly AM, Glisson JR, McDougald LR, Swayne DE, editors. Diseases of poultry. 11th ed. Ames: Iowa State University Press; 2003; p.182-202.

Schat KA. Chicken infectious anaemia. Iowa State University Press, Ames, USA. Curr. Topics Microbiol. Immunol. 2009; 331: 151 - 183.

Snoeck CJ, Komoyo GF, Mbee BP, Nakouné E, Le, Faou A, Okwen MP, Muller CP Epidemiology of chicken anemia virus in Central African Republic and Cameroon. Virology Journal 2012; 9:189.

Sommer $\mathrm{F}$ and Cardona $\mathrm{C}$. Chicken anemia virus in broilers: dynamics of the infection in two commercial broiler flocks. Avian Diseases, 2003; 47:1466-1473.

Todd D, Connor TJ, Calvert VM, Creelan JL, Meehan BM \& McNulty MS. Molecular cloning of an attenuated chicken anaemia virus isolate following repeated cell culture passage. Avian Pathol 1995; 24, 171-187.

Todd D. Avian circovirus diseases: lessons for the study of PMWS. Veterinary Microbiology 2004; 98:169174.

How to cite this article:

Sandhya N., K. V. Subramanyam, D. V. R. Sai and Gopal D. V. R. 2017. Isolation, Cultivation and PCR Conformation of Chicken Anaemia Virus Isolates in Broiler Chicks of Coastal Region of Andhra Pradesh, India. Int.J.Curr.Res.Aca.Rev. 5(12), 40-45. doi: https://doi.org/10.20546/ijcrar.2017.512.006
Toro H, Gonzalez C, Creda L, Hess M, Reyes E and Geisse C. Chicken anemia virus and fowl adenoviruses: Association to induce the inclusion body hepatitis hydro pericardium syndrome. Avian Dis, 2000; 44: 51-58.

Van Den Berg TP. Immuno depressive viral diseases in poultry: Current situation and perspectives. Poult. Advisor, Nov. 1996; 17-25.

Vielitz E, Von Bulow V, Landgraf H, and Conrad C. Anemia in broilers: development of a vaccine for parent stock. J. Vet. Med. 1987; B34:553-557.

Von Bulow V, and Schat KA. Chicken Infectious Anemia; Pages 739-756 in: Diseases of Poultry. Chapter 30. Iowa State University Press; Ames, IA, 1997.

Von Bulow V. Avian infectious anemia and related syndromes caused by chicken anemia virus. Crit. Rev. Poult. Biol. 1991; 3:1-17.

Yuasa N, Imai K, Watanabe K, Saito F, Abe M, Komi K. Aetiological examination of an outbreak of haemorrhagic syndrome in a broiler flock in Japan. Avian Pathology. 1979; 16:521-526.

Yuasa N, Taniguchi T \& Yoshida I. Isolation and some characteristics of an agent inducing anemia in chicks. Avian Diseases, 1979; 23,366-385. 